\title{
Merging Manual and Automated Egg Candling: A Safety and Social Solution
}

\section{(Combinando la ovoscopía manual y automática: una solución segura y socialmente responsable)}

\author{
Vargas Cruz Ramiro Sebastián ${ }^{1}$, Ruiz Salvador Lourdes Cecilia², Navas Lema María \\ Cristina $^{3}$
}

\begin{abstract}
:
Eggs should comply with strict quality control processes. The first step of the quality process is egg candling analysis. Egg candling is a non-destructive procedure that consists on applying light against an egg to detect abnormalities. This process is usually done manually at small and medium poultry factories. Manual egg candling is prone to human mistakes and can cause health problems to the workers. It is necessary to implement an automated process. The following study briefly describes a device that merges automated and manual egg candling analysis. Furthermore, it goes beyond the design and describes valid solutions regarding occupational safety and malnutrition that can emerge due to the implementation of this innovative design.
\end{abstract}

Keywords: Egg candling; mechatronic design; quality control.

\begin{abstract}
Resumen:
En la industria avícola los huevos deben cumplir con altos estándares de calidad. EI primer paso en el proceso de calidad, es el análisis por ovoscopía, el cual es una inspección no destructiva que consiste en aplicar luz sobre la muestra para detectar anormalidades. Generalmente este proceso se realiza de forma manual en pequeñas y medianas industrias avícolas del Ecuador. La ovoscopía manual es susceptible a errores humanos y genera problemas de salud en trabajadores tales como: trastornos oculares por trabajar prolongadas horas en cuartos oscuros; y problemas ergonómicos a largo plazo debido a que es una tarea monótona ejecutada a diario. Por lo tanto, la implementación de un proceso automatizado resulta relevante para el mejoramiento y seguridad del proceso. El siguiente estudio describe el diseño mecánico, eléctrico, electrónico y el método de procesamiento digital de imagen aplicado a la ovoscopía obtenida de las muestras. La innovación de este equipo reside en la posibilidad de realizar el análisis automático y adicionalmente una inspección manual de los huevos, lo cual mejora la efectividad del proceso. Su accesibilidad económica y versatilidad de manejo automático/manual la destacan entre dispositivos comercialmente similares. Además, va más allá del diseño y describe soluciones válidas en materia de seguridad laboral y desnutrición que pueden surgir gracias a la implementación de este innovador diseño.
\end{abstract}

Palabras clave: Ovoscopía; diseño mecatrónico; control de calidad.

\footnotetext{
1 Universidad Técnica de Cotopaxi, Latacunga, Ecuador (ramiro.vargas@utc.edu.ec)

2 Obuda University, Budapest, Hungría (lourdes.ruiz@bgk.uni-obuda.hu)

3 Universidad de las Fuerzas Armadas ESPE, Sangolqui, Ecuador (mcnavas@espe.edu.ec)
} 


\section{Introduction}

Eggs are a highly nutritious food product. The egg white is a good source of vitamins such as D, B2, B6, B12 and minerals such as selenium, zinc, iron and copper. Egg yolks contain fat, cholesterol and vitamins such as A, D, E and K. They are a considered an inexpensive and high-quality protein source. They contain all the essential amino acids that cannot be synthesized in the human body and should be obtained from the diet (Lewin, 2017). Eggs should comply with strict quality control standards in order to be suitable for human consumption. The first step in the egg quality control process is to detect obvious defects. This step is accomplished through egg candling.

Egg Candling is a nondestructive selection method that consists on applying a bright light against an egg to detect abnormalities. It is crucial to recognize the defects inside the egg, thus an analysis beyond superficial vision should be performed (Abdullah, Nashat, Anwar, \& Abdullah, 2017). Egg candling is carried out in a dark room where the light penetrates the egg's shell, making the shell transparent and able to examine the eggs' internal components (Arivazhagan, Shebiah, Sudharsan, Kannan, \& Ramesh, 2013). This process detects blood stains, spots, cracks, enlarged air cells and fertilized eggs (Ragni, Cevoli, \& Berardinelli, 2010). Table 1 shows pictures of egg defects detected using egg candling analysis. Candles were used in the past as a source of light for performing egg candling analysis, therefore its name nowadays (United States Department of Agriculture, 2010).

Table 1. Pictures of egg's defects using the egg candling method presented in this study

\begin{tabular}{llllll}
\hline $\begin{array}{l}\text { Type of } \\
\text { Defect }\end{array}$ & Linear Rupture & Body Check & Cage Marks & No defects \\
\hline Picture
\end{tabular}

At small, medium companies and in developing countries; this quality control process is usually done manually. This procedure is carried out by an operator who based on his knowledge detects the eggs' defects and remove them from the production line (Arango, 2013). The efficiency of this analysis relies solely on the worker's skills and experience. Therefore, the manual process is prone to mistakes. Automated processes are used to inspect large quantities of eggs; nevertheless, individual sampling is still relevant for egg quality control and egg grading (Liu, Ter Hsin Chen, \& Tan, 2017). Egg candling automated systems are essential to determine if an egg is fertile at poultry factories, for this reason a machine vision device was built for inspection (Hashemzadeh \& Farajzadeh, 2016).

Egg candling analysis entails several health problems to the worker. It implies an exposition to a high-intensity light and to work in a dark room during long periods of time. As a result, the operator progressively damages his eye vision and develops other health issues (Brereton, 1996). For this reason, it is essential to develop a system that can be able to offer a manual sampling and an automated process in order to provide a total quality control process.

The following study briefly describes the innovative design of an egg candling device that combines manual and automated procedures. Furthermore, this study goes beyond the design and enumerates real-life solutions regarding occupational safety and malnutrition due to the implementation of this device. 


\section{Methodology}

The device design consists of three parts:

2.1. Mechanical design, which comprises of a conveyor belt with a ramp that allows the samples to enter to the device and then be distributed in two lateral conveyor chains. Each conveyor chain carries the eggs to the inspection chamber which prevents external light interference with the egg-candling analysis. Additionally, six lateral mechanisms were designed to push the abnormal eggs to the central conveyor belt. At the exit of the inspection chamber, only samples with high-quality egg shell, remain at the lateral conveyor chains for the following process. Figure 1 is a general 3D scheme of the mechanical system designed in SolidWorks@.

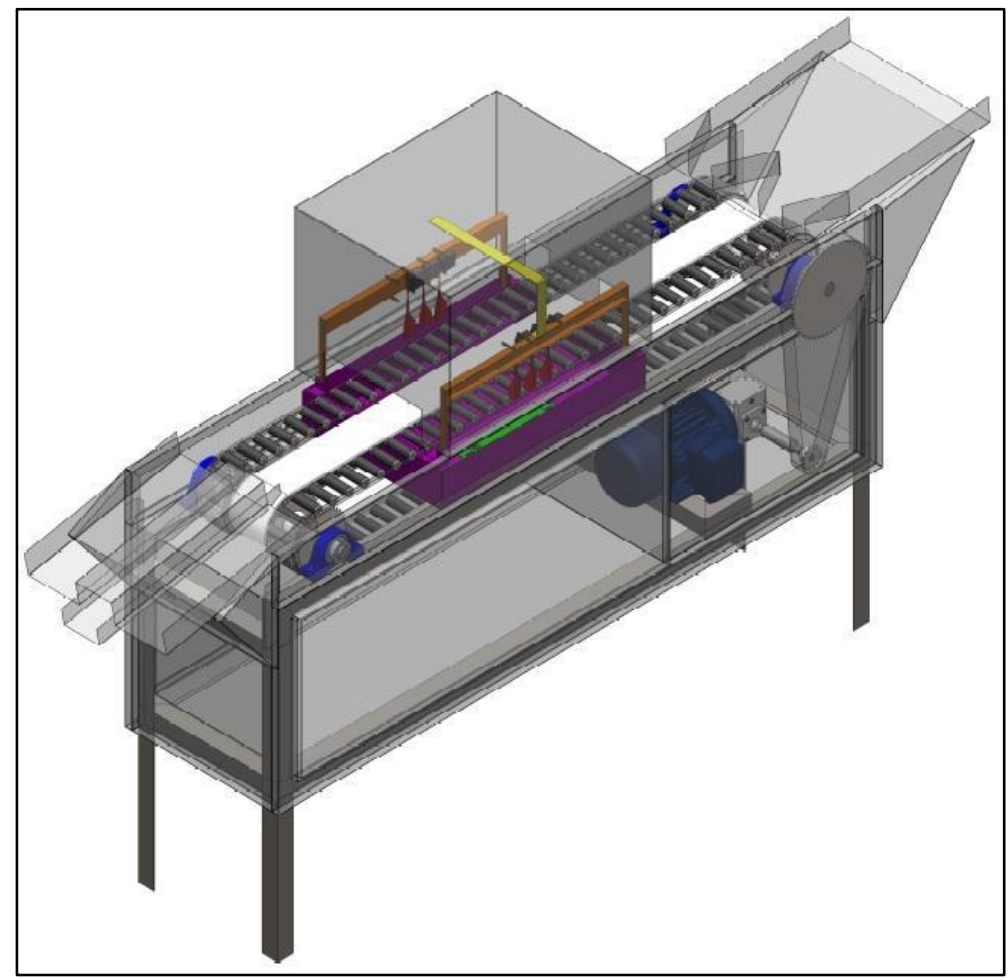

Figure 1. 3D Modelling of the Mechanical System

The two conveyor chains were designed using recycled materials and soft fasteners. Bicycle chains and bicycle spokes are the main structure of the conveyor chain. A nylon rivet and a sponge fastener cover each spoke. The distance between spokes and its length was designed according to an average egg size. The design keeps each sample in its own space, avoiding undesired movements that can cause breakage. It also allows samples to be candled at the inspection chamber.

Inside the inspection chamber, there are three mechanisms on each side, two web cameras on top and 6 light valves on the down part for lightening. A lever, driven by a servomotor, softly pushes the egg to the central conveyor belt. The candling analysis is performed utilizing dichroic light bulbs. The device uses a cold light in order to prevent physical damage to the egg yolk due to high temperature. Two web-cameras (3.5 megapixels resolution) were used to take the images of the upper view (Figure 2). 


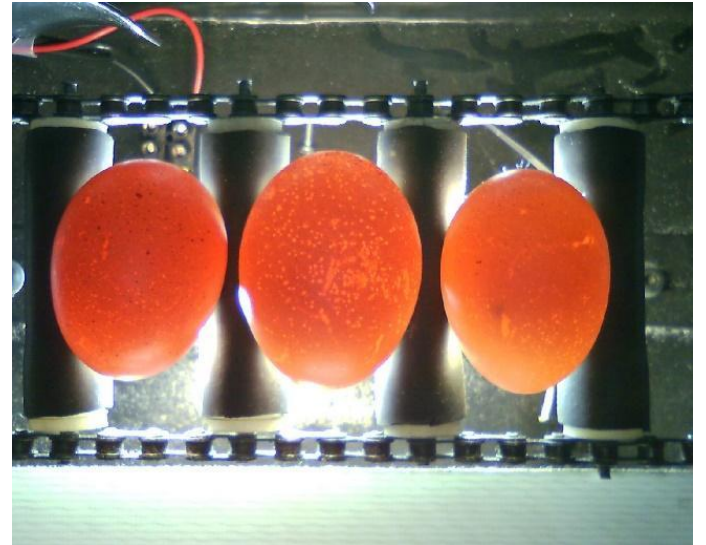

Figure 2. Egg-candling, image acquisition of the samples' upper view

Image processing analysis. The selection process is based on the detection of abnormalities on the egg-shell. Each camera acquires an image of three samples at one time. The picture is sent to the computer and processed by an algorithm developed in Matlab®. After a digital image processing, the software decides whether the sample is appropriate for incubation or not, based on the number of abnormalities detected. Moreover, a Graphic User Interface (GUI) shown in Figure 3, was created for two purposes: supervision and self-selection. In the supervision mode (automatic method), the operator can only inspect the selection process ran by the software. In the self-selection mode (manual method), the worker chooses samples with abnormalities based on his own experience and empiric knowledge to validate the automated process.

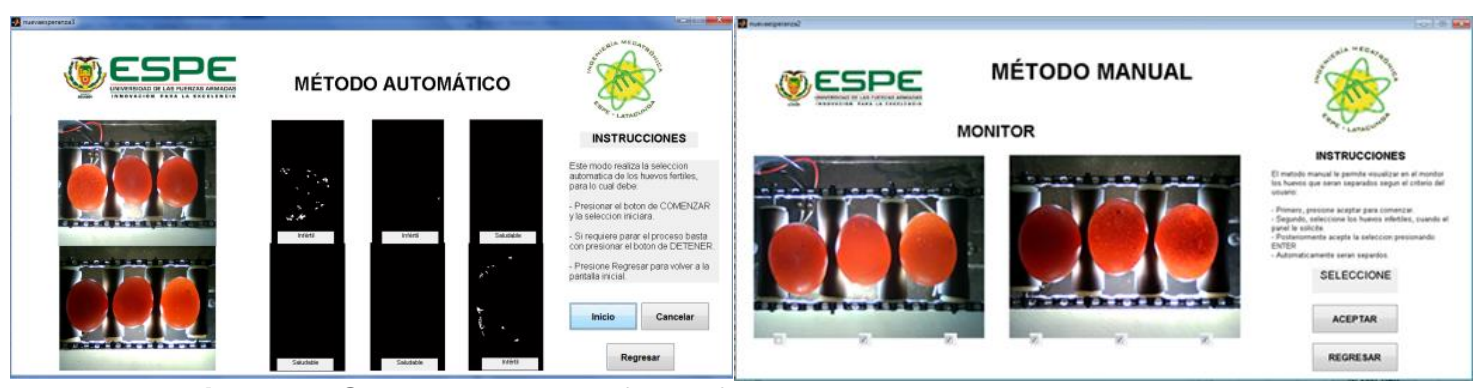

Figure 3. Graphic User Interface of the system - automatic and manual method

2.2. Electronic Design. The conveyor belt works using an electric motor controlled by a variable frequency drive. Previously, it was mentioned that the selection mechanisms were driven by servo motors and the digital image processing was developed in Matlab ${ }^{\circledR}$. Thus, high voltage, electronic instrumentation voltage, and serial communication were synchronized to work effectively using an ARDUINO UNO board. Figure 4 displays the electric control panel; sensors and actuators were placed in specific positions over the system and then connected to the board.

\section{Results}

The main result obtained in this study is the design and construction of an egg candling device that combines manual and automated analysis. It was a complex process that involved mechanical, electronic design and the core of the device that is the image processing algorithm which analyzes the eggs.

The system can process one egg per second, in 8 hours of workday it can analyze 48000 eggs. Additionally, analyzing 1000 eggs, the effectiveness of the device is $95 \%$. Table 2 shows the results obtained using the device for selecting fertile eggs. 


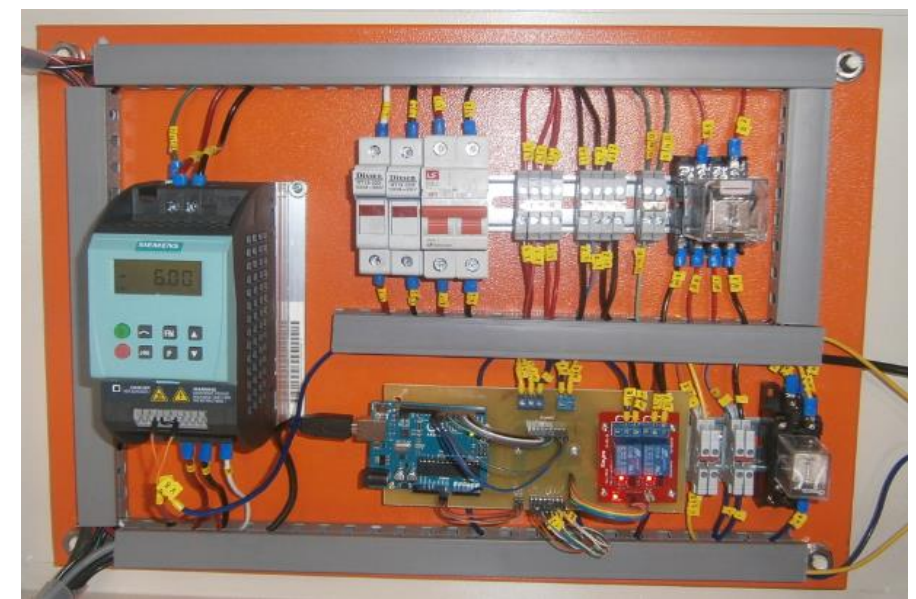

Figure 4. Electric control panel of the system

Table 2. Results of the analysis of 1000 eggs in the egg candling device

\begin{tabular}{|c|c|c|c|}
\hline \multicolumn{2}{|c|}{$\begin{array}{c}\text { Number of fertile eggs selected by the } \\
\text { system }\end{array}$} & \multicolumn{2}{c|}{$\begin{array}{c}\text { Number of infertile eggs selected by the } \\
\text { system }\end{array}$} \\
\hline \multicolumn{2}{|c|}{683} & \multicolumn{2}{c|}{317} \\
\hline $\begin{array}{c}\text { Number of } \\
\text { eggs hatched }\end{array}$ & $\begin{array}{c}\text { Number of eggs } \\
\text { not hatched }\end{array}$ & $\begin{array}{c}\text { Number of } \\
\text { eggs hatched }\end{array}$ & $\begin{array}{c}\text { Number of eggs not } \\
\text { hatched }\end{array}$ \\
\hline 647 & 36 & 21 & 296 \\
\hline
\end{tabular}

\section{Discussion}

\subsection{Social solution}

The egg candling device was designed and tested at a medium-sized poultry factory located in the center area of Ecuador. Before the device introduction, this company performed the egg candling analysis manually. The selected eggs obtained in this analysis were used for the incubation process. The results of the selection process were seen just after 21 days which is generally the hatching time in poultry. This process was not accurate; approximately 20 to 40 percent of the incubated eggs did not hatch. These eggs were considered waste and could not be used for other purposes. This automated process diversifies the company's business letting a timely usage of the non-fertile eggs for other purposes. An important usage is human consumption since the eggs that were not selected for the incubation process are edible.

Ecuador has a serious infant malnutrition problem. The average rate in Ecuador is $25 \%$, but in provinces such as Chimborazo, Bolivar and Santa Elena, malnutrition rates are startling higher: 48.8\%, 40.8\% and 37.3\% respectively (El Universo, 2016). Child malnourishment is the main cause of stunting, infection proneness and infant diseases. In order to tackle this problem, the "lulun project" taken place in Cotopaxi province of Ecuador, proposed the usage of eggs as complementary feeding for toddlers. Eggs are an inexpensive and more accessible high protein source for the low-income population than fortified foods. This study showed that the ingestion of one egg per day can reduce the prevalence of stunting by $47 \%$ and underweight by $74 \%$ compared with the control group that did not receive eggs (lannotti, et al., 2017).

This device will be able to reduce the gap between the access to protein and children of low-income; trying to lessen the social problem of malnutrition. Moreover, the analysis capacity of this device is higher in comparison with a manual selection. The manual analysis done at the studied poultry factory was able to examine 50000 eggs per month whilst the automated process performed by the device can inspect 48000 eggs in 8 hours of work. The egg candling device widely overcomes the manual selection capacity. Considering that 
the provinces of Tungurahua, Cotopaxi and Chimborazo constitute $65 \%$ of the national egg production (Moreta, 2016) the device augmented capacity opens up several opportunities to the poultry industry in these areas. Few of the new opportunities emerging due to the application of this device are: increasing the production, renting the device to small and medium companies, which can lead to more available, cheaper and high-quality eggs for the communities nearby which are vulnerable to malnutrition.

\subsection{Occupational safety}

The design of the egg candling analysis device was planned and carefully thought to minimize or solve main health issues that can be caused by a constant manual egg candling analysis. Ergonomic principles were applied throughout all the design process in order to create an equipment and process that fits the worker's body instead of forcing the worker to adjust to the machine (Occupational Safety and Health Administration, 2000).

Manual egg candling is performed in dark rooms in order to be able to observe the internal components of the egg. Working in a poor illumination area can cause, stress burnout and accidents. Furthermore, it can lead to health issues such as eye strain, headaches and musculoskeletal disorders. A person that works extended hours on artificial light can suffer an unbalance of the body's natural rhythms that in a long- term can cause depression (Occupational Safety and Health Administration, 2000). The built-in inspection chamber on the device protects the worker's vision by performing the egg candling in this chamber. The worker just needs to place the eggs and run the system without the necessity of spending his working hours in a dark room.

Manual egg candling requires repetitive tasks and high specialization. These tasks are done for a long period of time on a daily basis. This type of work affects the employee's' health by creating stress on their bodies which can lead into injuries and serious workrelated accidents (Occupational Safety and Health Administration, 2000). The automated process performed by the designed device reduces monotonous tasks by giving the worker the function of supervising the whole process. In addition, the worker performs manual candling on a reduced number of samples for quality control. For this purpose, a friendly GUI was included in the device, so the worker can control the process and inspect the product.

The ergonomic design of the egg candling equipment focuses on providing a safe and healthy work environment to the employees. Moreover, the automation of the process empowers the workers to perform more meaningful tasks that will enhance the quality of the product and have a positive impact on their health and professional goals.

Interpretar los resultados de acuerdo con estudios similares, es decir correlacionar los resultados del estudio con otros realizados, enunciar ventajas del estudio, sus aportaciones, evitando adjetivos que elogien los resultados.

Esta sección y la anterior pueden presentarse en una sola sección llamada Resultados y Discusión. En un artículo de revisión, esta sección suele no ser necesaria.

\section{Conclusions and recommendations}

It is essential to see beyond the design and construction of the egg candling device in order to enumerate and describe real-life solutions. The main goal of this work is to present two problems that can be solved due to the implementation and integration of an innovative device. As described above the fast selection analysis executed by the automated egg candling process can provide inexpensive high-quality protein to low-income families and also tackle in some degree the serious problem of malnutrition in Ecuador. In addition, the ergonomic design proposed for this device offers a valid solution regarding occupational safety. Most of the health problems encountered during manual egg candling are resolved, offering the worker a safe work environment and a reduction in work-related accidents. 
The automation of the egg-candling analysis in poultry industries in Ecuador can clearly contribute to a sustainable development and improvement in chicken production. However, the concept of automation is usually linked to layoff. It may seem that a machine could replace an operator's job. Nevertheless, a better pre-incubation analysis leads to an increment in chicken production. Consequently, human resources are needed to properly raise the chickens and keep the production quality. Thus, instead of redundancy, a poultry factory would need to hire more people.

\section{Bibliography}

Abdullah, M., Nashat, S., Anwar, S., \& Abdullah, M. (2017). A framework for crack detection of fresh poultry eggs at visible radiation. Computers and Electronics in Agriculture, 81-95.

Arango, J. (2013, March 5). Calidad Externa e Interna del Huevo. Retrieved from AVICOL Genetica Animal: http://avicol.co/descargas2/CalidadExternalnternaHuevo.pdf

Arivazhagan, S., Shebiah, R. N., Sudharsan, H., Kannan, R. R., \& Ramesh, R. (2013). External and internal defect detection of egg using machine vision. Journal of Emerging Trends in Computing and Information Sciences, 257-262.

Brereton, P. (1996). Authentication of eggs and egg products. In P. R. Ashurst, \& M. J. Dennis, Food Authentication (pp. 339-350). London: Blackie Academic \& Proflessional.

El Universo. (2016, September 4). La desnutrición infantil, un mal que cuesta revertir. Informes - El Universo. Retrieved from Informes - El Universo: https://www.eluniverso.com/noticias/2016/09/04/nota/5780076/desnutricioninfantil-mal-que-cuesta-revertir

Hashemzadeh, M., \& Farajzadeh, N. (2016). A Machine Vision System for Detecting Fertile Eggs in the Incubation Industry. International Journal of Computational Intelligence Systems, 850-862.

lannotti, L. L., Lutter, C. K., Stewart, C. P., Riofrio, C., Malo, C., Reinhart, G., . . Waters, W. (2017). Eggs in Early Complementary Feeding and Child Growth: A Randomized Controlled Trial. Pediatrics, 1-9.

Lewin, J. (2017, July 18). The health benefits of eggs. Retrieved from goodfood: https://www.bbcgoodfood.com/howto/guide/ingredient-focus-eggs

Liu, Y. C., Ter Hsin Chen, Y. C., \& Tan, F. J. (2017). Determination of the quality of stripemarked and cracked eggs during storage. Asian-Australasian journal of animal sciences, 1013-1020.

Moreta, M. (2016, February 23). Los productores de huevos de Tungurahua temen una quiebra. El Comercio.

Occupational Safety and Health Administration. (2000). Ergonomics: The Study of Work. Washington, DC: United States Department of Labor.

Ragni, L., Cevoli, C., \& Berardinelli, A. (2010). A waveguide technique for non-destructive determination of egg quality parameters. Journal of food engineering, 343-348.

United States Department of Agriculture. (2010). Manual, EGG-Grading. Washington, D.C.: Agricultural Marketing Services. 